\title{
Tuotantorakennusten toiminnan suunnittelu 3D -pelitekniikalla
}

Urpo Manninen $^{1)}$, Risto Kauppinen ${ }^{2)}$, Veikko Tuovinen ${ }^{2)}$, Jaakko Mononen ${ }^{3)}$

1) FarmiMalli Oy, Mäkipirtinkatu 18, 70820, Kuopio.urpo.manninen@farmimalli.fi

2) Savonia-ammattikorkeakoulu, PL 72, 74101, Iisalmi.etunimi.sukunimi@savonia-amk.fi

3) Kuopion yliopisto, Soveltavan biotekniikan instituutti, PL 1627, 70211Kuopio, etunimi.sukunimi@uku.fi

\section{Tiivistelmä}

Tällä hetkellä käytettävät CAD -järjestelmät soveltuvat parhaiten rakennuspiirustuksien tekniseen julkaisuvaiheeseen. Näillä ohjelmilla toteutetuista 2D -piirroksista on vaikea hahmottaa maatalouden tuotantoprosessin toimivuutta.

Lasten peleistä tuttu 3D -tekniikka auttaa tuotantorakennusten toiminnan hahmottamista alkusuunnitteluvaiheessa.

3D -pelitekniikka mahdollistaa helpon tavan tutkia ja havaita aiotun rakennuksen toiminnallisuutta. Tuottaja voi itse kokeilla erilaisia toimintamalleja ja niiden kustannuksia ennen varsinaisen suunnitteluprosessin aloittamista.

Alkusuunnitteluvaihe vaatii monen alan asiantuntijoita, joiden on usein vaikea ilmentää tahtoaan suunnitteluprosessissa. He eivät välttämättä ymmärrä 2D -piirroksissa esitettyä toimintamallia sillä tavalla kuin rakennusalan ammattilainen.

3D -peliteknologian antama kolmiulotteinen läsnäolon tuntemus ja tämän kautta rakennuksen toimivuuden ymmärtäminen tuo suunnittelun eri vaiheisiin osallistuvien tahojen käyttöön uuden lähestymistavan. Kaikki suunnitteluprosessiin osallistuvat voivat esittää ja kokeilla uusia ideoita 3D mallin avulla ja toteuttaa ne helposti ymmärrettävässä muodossa.

Toimintamallista saadaan IFC -tallennuksen kautta siirrettyä siihen kertynyt tieto suoraan loppusuunnittelijan CAD -ohjelmaan.

Navetoiden toiminnallinen suunnittelu saa uuden havainnointimahdollisuuden, kun eläinten liikkumista ja käyttäytymismalleja voidaan soveltaa toiminnallisessa suunnittelussa. Alkusuunnittelu voidaan uudella järjestelmällä toteuttaa ilman rakennussuunnitteluun perehtynyttä henkilöä, tällöin tuottajalla itsellään on entistä paremmat mahdollisuudet osallistua tuotantorakennuksensa toiminnalliseen suunnitteluun. Nettiversion avulla myös muut asiantuntijatahot esimerkiksi eläinlääkärit voivat osallistua rakennuksen toiminnalliseen suunnitteluun. Virtuaalipeleistä tuttu 3D-tekniikka parantaa huomattavasti eläinten terveyden ja hyvinvoinnin seurantaa suurissa eläinyksiköissä.

3D -pelitekniikaan perustuva rakennussuunnitteluohjelma on tällä hetkellä koekäyttövaiheessa Atria OYj:n nautaryhmässä.

Asiasanat: 3D-visualisointi, rakennussuunnittelu, naudat, tuotantoeläinten käyttäytyminen, eläinterveys 


\section{Tausta}

Suomessa ja uusissa EU-yhteisön jäsenmaissa maatalouden rakenteen muuttumisen vuoksi rakennetaan seuraavan vuosikymmenen aikana lähes koko tuotantorakennuskanta uudestaan. Suomessa on ongelma saada ammattitaitoinen suunnittelija mukaan toiminnallisen suunnittelun vaiheeseen. Suunnittelijoista osa siirtyy samana aikana eläkkeelle, jolloin tilanne vaikeutuu entisestään. Voimme parantaa tilannetta vapauttamalla vähäisiä arkkitehtiresursseja tuotantorakennusten toiminnallisesta suunnittelusta arkkitehtipiirrosten tekemiseen.

Suunnitteluprosessiin osallistuvat asiantuntijat seuraavista jaksoissa:

\section{RAKENNUTTAJA}

Ajatus rakentamisesta

Aikataulu

Liiketaloussuunnitelma

+ TUOTANTOASIANTUNTIJA

Toiminnallinen suunnittelu, rakennuttaja ja tuotantoasiantuntija

+ RAKENNUSSUUNNITELIJA

Ympäristölupa, rakennussuunnittelija

Rakennuslupa

Investointitukihakemus

+ RAKENNE- ja MUUT ERIKOISSUUNNITTELIJAT

Rakennesuunnittelu

LVI -suunnittelu

Sähkösuunnittelu

\section{Historia}

80 -luvun lopussa alkoi tietokoneavusteinen rakennusten suunnittelu (CAD). Ohjelmat olivat tehokkaita, mutta samalla vaikeita oppia käyttämään. Ohjelman käytön pystyi opettelemaan vain sitä ammatikseen tarvitsevat rakennusten suunnittelijat. Tietokoneavusteisen suunnittelun yleistyminen toi rakennussuunnittelijat myös toiminnallisen suunnittelun vaiheeseen, koska muuten toiminnallista ei saatu kuvattua. Ennen $\mathrm{CAD}$-ohjelmia tuotantoasiantuntijat yhdessä tuottajan kanssa pystyivät miettimään rakennuksen toimivuutta ilman arkkitehdin läsnäoloa. Rakennuksen toimintamalli piirrettiin ruutu- tai millimetripaperille kynällä ja viivaimella. Kustannustaso selvitettiin ohjekustannustaulukolla. Rakentamispäätöksen jälkeen tuotantoasiantuntijan tekemä toimintaluonnos toimitettiin rakennussuunnittelijalle, joka virallisti suunnitelman rakennuslupaa ja investointitukihakemusta varten. Meijereillä ja teurastamoilla oli tuotantoneuvojat, jotka auttoivat tuottajaa toiminnallisen suunnittelun vaiheessa.

\section{FarmiMalli -ohjelman asema suunnitteluprosessissa}

FarmiMalli -ohjelma on tarkoitettu suunnitteluprosessin alkuvaiheeseen. Nyt käytössä olevat CAD ohjelmat eivät vaikeasti opittavina sovellu toiminnallisen suunnitteluun tuottajan ja tuotantoasiantuntijan apuvälineeksi. Savonia-ammattikorkeakoululla kehitetty "Läpinäkyvä rakennussuunnittelu"-konsepti toi toiminnallisen suunnittelun lähemmäs ei-rakennusalan ammattilaisia ja mahdollisti erialojen asiantuntijoiden osallistumisen suunnitteluun internetin kautta. Suunnitelmien kommentointi tapahtui 2D"punakynätoiminnalla".

FarmiMalli -ohjelma on tarkoitettu suunnitteluprosessin toiminnallisen suunnittelun apuvälineeksi, jolla tuottaja asiantuntijan kanssa voi tehdä 3D -mallin joka havainnollistaa toiminta-ajatuksen ymmärrettävään muotoon 3D -peliohjelmien tapaan. Kommentointi tapahtuu suoraan 3D-malliin. 


\section{Uusia toimintoja suunnitteluprosessissa}

"Chat" keskustelutekniikka suunnittelutyöryhmässä

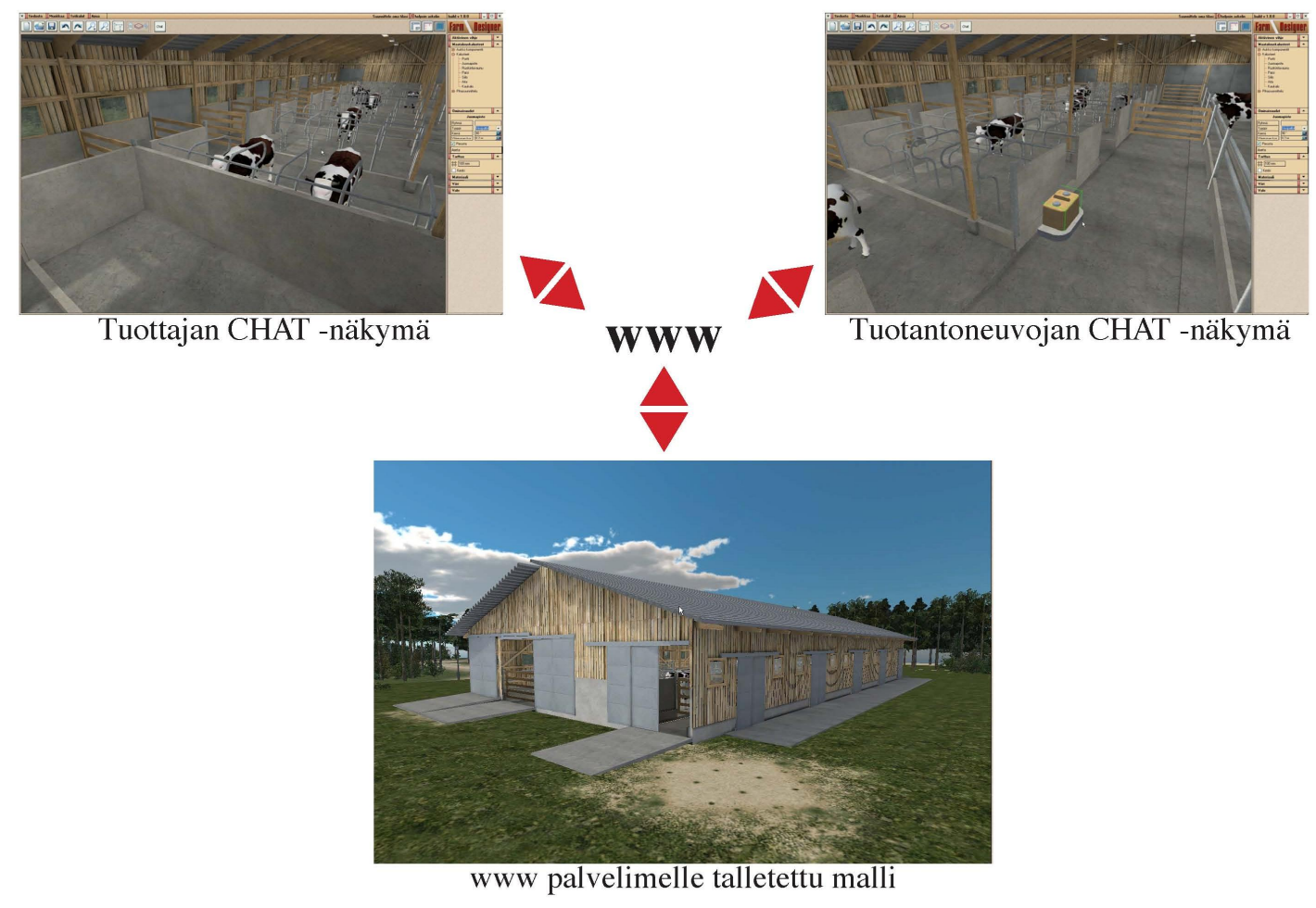

Kuva 1. Toimintakaavio tietoverkon käytöstä suunnitteluryhmässä

Rakennusta voidaan hahmotella internetin läpi "chat" tekniikalla. Kukin vuorollaan on puheenjohtaja, joka päivittää 3D -mallia. Tehdyt muutokset näkyvät kaikilla työryhmän jäsenillä välittömästi. "Chat" mahdollistaa myös kirjoitetun viestityksen osallistujien kesken. 3D -mallissa on määrälaskuri, jonka tiedoista erillinen "kustannuslaskuriohjelma" päivittää suunnitellun rakennuksen kokonaishintaa. Hinta näkyy mallinnusohjelman näkymässä. Kun malliin lisätään uusia rakennusosia, hinta päivittyy vastaavasti.

\section{Visuaalinen simulointi 3D - mallissa on mahdollista lähitulevaisuudessa}

3D -mallissa voidaan esittää vastaavan todellisen navetan eläinten ja muidenkin liiketunnistimella varustettujen asioiden liikkuminen reaaliaikaisena tai vaihtoehtoisesti jokin aiemmin tallennettu jakso. Eläimet ovat varustettu liike- ja kiihtyvyysantureilla. Liikeanturin tieto välittyy tietoverkon kautta 3D malliin. Rakennuksen 3D -mallissa eläinten näköismallit näkyvät todellisen paikkansa mukaisessa tilassa. Kiihtyvyysantureilla mallissa näkyvään eläinhahmoon välitetään tieto myös poikkeamatilasta verrattuna normaaliin käyttäytymiseen. Eläinmalli näyttää ontuvalta, jos todellisessa navetassa vastaava eläin ontuu. Jos epäillään tapaturmaa, niin historiatiedoista saadaan selville missä tilanteessa tapaturma on sattunut. Voimme etsiä rakennuksesta mahdollisia tapaturman aiheuttajia ja poistaa ne. Vastaavasti uusissa rakennuksissa näitä ratkaisuja pyritään välttämään. Tulevaisuudessa voimme seurata todellisen tuotantorakennuksen eläinten käyttäytymistä ja hyvinvointia virtuaalimallin avulla kotitietokoneen näytöltä reaaliaikaisena tai tallennettua historiatietoa esimerkiksi edellisen yön kiimakäyttäytymisestä. 
Mallin toimintoja seuraavat asiantuntijat luovat uusia ideoita kokeiltavaksi käytäntöön. Kuopion yliopiston, Savonia-ammattikorkeakoulun ja VTT:n yhteisessä "Hyvin älykäs navetta" - hankkeessa (HÄN-hanke) on tarkoitus selvittää tarpeellinen määrä pihatossa pidettävien lypsylehmien tavallisimpia käyttäytymismalleja. Hankkeen tutkimukselliseen osioon kuuluvaa kokeellista osaa toteutetaan Peltosalmen maatalousoppilaitoksen lypsykarjapihatossa. Nämä käyttäytymismallit voidaan toteuttaa ja näyttää 3D-mallissa animaatioeläinten hahmossa. Tulevaisuudessa on mahdollista tehdä tekoälyinen ohjelma, jolla voi kokeilla uusien asioiden vaikutusta eläinten käyttäytymiseen. Tekoälyohjelman pohjana käytetään isoa historiatietokantaa joka on tallennettu oikeasta tuotannosta. Kun tapahtumia on riittävästi, niistä voidaan tulkita erilaisten asioiden vaikutusta eläinten käyttäytymiseen.

Täysin "virtuaalisen" navetan tekeminen on mahdollista. Virtuaalisella alkumallinnuksella tuottaja voi kokeilla tulevan navettansa toimivuutta.

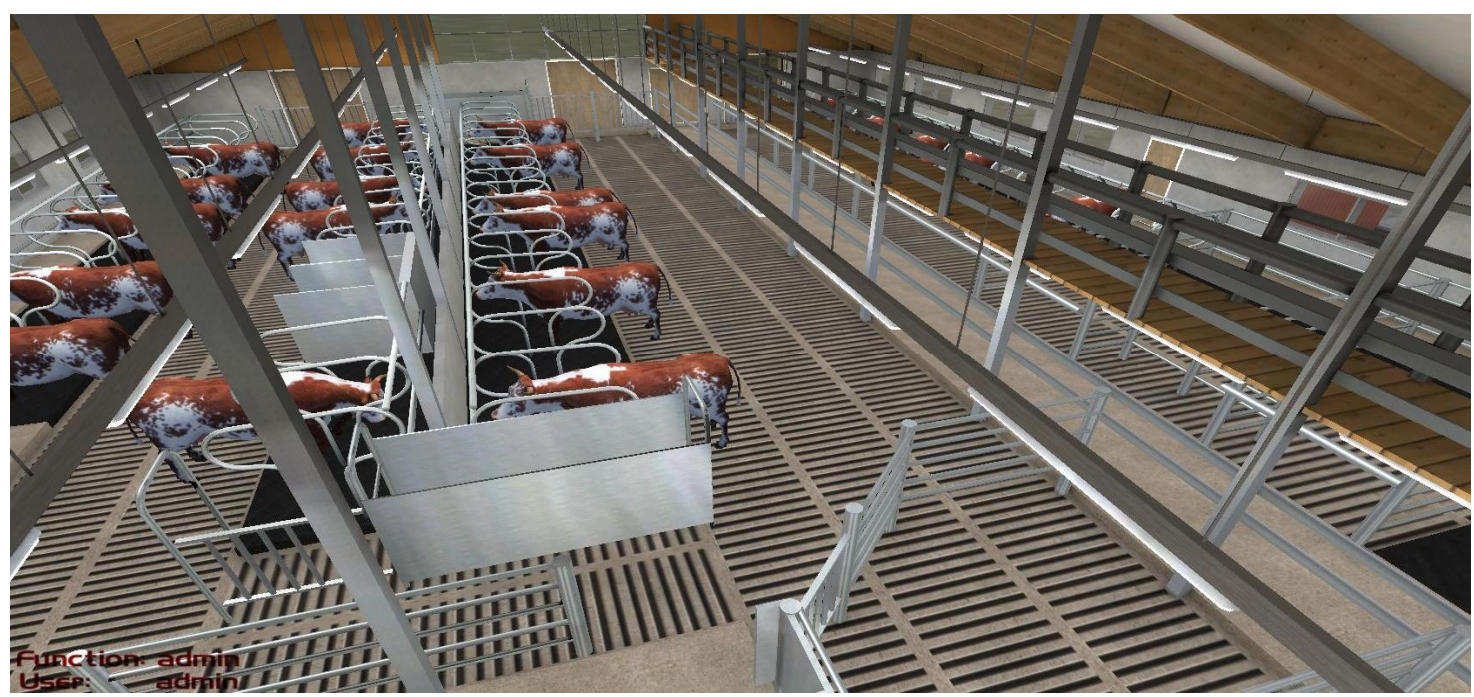

Kuva 2. Peltosalmen maatalousoppilaitoksen (Iisalmi) opetusnavetan 3D -pelimalli.

Peltosalmen maatalousoppilaitoksen navetassa lehmillä on liike- ja kiihtyvyysanturit. Navetoiden toiminnallinen suunnittelu saa uuden havainnointimahdollisuuden, kun eläinten liikkumista ja käyttäytymismalleja voidaan soveltaa toiminnallisessa suunnittelussa. Alkusuunnittelu voidaan uudella järjestelmällä toteuttaa ilman rakennussuunnitteluun perehtynyttä henkilöä, tällöin tuottajalla itsellään on entistä paremmat mahdollisuudet osallistua tuotantorakennuksensa toiminnalliseen suunnitteluun. Nettiversion avulla myös muut asiantuntijatahot esimerkiksi eläinlääkärit voivat osallistua rakennuksen toiminnalliseen suunnitteluun. Arkkitehti kutsutaan mukaan suunnitteluprojektiin antamaan rakennukselle ulospäin näkyvä muoto. Arkkitehti voi tietenkin osallistua jo toiminnallisen suunnittelun vaiheeseen.

Virtuaalipeleistä tuttu 3D-tekniikka parantaa huomattavasti eläinten terveyden ja hyvinvoinnin seurantaa suurissa eläinyksiköissä. 